\title{
МОВНА КАРТИНА СВІТУ ФУТБОЛЬНИХ ФАНАТІВ
}

\author{
ІРИНА ПРОЦИК \\ Львівський національний університет імені Івана Франка, Львів — Україна \\ JĘZYKOWY OBRAZ ŚWIATA KIBICÓW PIŁKARSKICH
}

\author{
IRYNA PROCYK \\ Lwowski Uniwersytet Narodowy im. Iwana Franki, Lwów — Ukraina
}

\begin{abstract}
STRESZCZENIE. W artykule przedstawiono zarówno specyficzne realia istotne dla środowiska ukraińskich kibiców piłkarskich, jak i specyficzną leksykę charakterystyczną dla tej subkultury. Językowy obraz świata kibiców omówiono na podstawie analizy słownictwa związanego z wartościami istotnymi dla członków tej grupy. Poczynione uwagi opierały się na aspektach werbalnej samoidentyfikacji kibiców, przede wszystkim na dyferencjacji kluczowych pojęć: „ultras” — „chuligans”. Ponadto przeanalizowano zasadniczą dla językowego obrazu świata kibiców piłkarskich opozycję „swój-obcy”, w której z punktu widzenia kibiców piłkarskich obcy to milicja, ochrona stadionu, sędziowie sportowi, funkcjonariusze futbolu itd. Ustalono, że leksyka w socjolekcie ukraińskich kibiców piłkarskich powstała na bazie semantyki słownictwa ogólnego języka ukraińskiego, a także jest wynikiem zapożyczeń z różnych języków i wpływu slangu młodzieżowego.
\end{abstract}

\section{LANGUAGE MAPPING OF FOOTBALL FANS' WORLD}

\author{
IRYNA PROTSYK \\ Ivan Franko National University of Lviv, Lviv - Ukraine
}

ABSTRACT. In this article specific realia which are typical for football fans environment have been examined; also vocabulary which denominates the peculiar world of representatives of this subculture has been considered. Language mapping of football fans' world has been described on the basis of the analysis of specific words reflecting values which are significant for the members of this social group. The stress has been made on the aspects of verbal self-identification of Ukrainian football fans, especially on differentiation of key notions such as „ultras” and „hooligans”. The pivotal opposition „own - alien” for this football fans group has been analysed, special attention has been paid to nominations which are used by football fans for naming police, stadium securities, referees, football officials, etc. It has been found out that the lexemes of the social dialect of Ukrainian football fans were for the most part created due to expansion of semantics of commonly used words of the Ukrainian language and also loanwords from different languages and youth slang.

лексиці соціолектів зафіксовано висловлювання, що вказують на специфічний характер буття та життя представників певних соціальних груп; ці специфічні слова нерідко зрозумілі тільки групі людей, які творять цю суспільну групу, адже вони пов'язані спільними інтересами. Ця лексика номінує чи характеризує специфічні реалії, важливі для певного середовища і які є несуттєвими поза цим середовищем, а тому найчастіше не мають назв у загальновживаній мові. Лексика соціолектів презентує спільні цінності, вагомі для членів цієї групи, вказує на їхнє ставлення до дійсності. 
Завдання статті - з'ясувати, як за допомогою слів футбольні фанати пізнають, освоюють й омовлюють навколишній світ. Аналіз специфічних лексем із фанатського соціолекту дасть можливість зрозуміти, яким є своєрідний світ фанатів футболу, відображений у лексиці цього соціолекту.

Лексичні засоби є сутністю соцілекту, основним елементом, який відрізняє мовлення окремої групи людей, пов'язаних певними соціальними узами, від мовлення загалу. „Лексика соціолектів виконує функції інтеграції певного середовища та ідентифікації його членів"1. Якщо хтось розуміє ці слова та висловлювання й уживає їх, то належить до цього грона. Уживання відповідної лексики $є$ також засобом виокремлення себе від інших суспільних груп.

Мовна картина світу футбольних фанатів засвідчує, що найбільш розвиненою в цьому соціолекті є лексика, яка стосується реалій, що в бутті цієї суспільної групи відіграють найважливішу роль — спільне вболівання за певну футбольну команду.

В Україні, як і в більшості слов'янських країн Європи, футбольне фанатство розквітло лише на початку 90-х років XX століття, хоча перші спроби об'єднання навколо вболівання за улюблений клуб почалися ще в 70-80-х pp.

Екскурс в історію футбольного фанатизму засвідчує, що батьківщиною футбольного фанатського руху, як і самого футболу, була Великобританія ${ }^{2}$. Родоначальниками ж фанатського руху прийнято вважати уболівальників лондонського „Міллуолла”. Саме вони наприкінці 50-х рр. влаштували організовану підтримку своєї команди під час футбольного матчу. Знадобилося зовсім небагато часу, щоб майже в кожного клубу на Туманному Альбіоні з'явилися свої фанатські угруповання. У 50-х рр. виникли групи підтримки футбольних команд у Південній Америці (насамперед у Бразиліi). У 60-х рр. футбольний фанатизм набув масовості в Італії, а в 70-х рр. активна підтримка на трибунах під час матчів почала поширюватись по всіх європейських стадіонах. Однак фанатський рух кожної країни мав свої особливості.

За понад п'ятдесятирічну історію розвитку футбольного фанатизму сформувалися два провідні стилі вболівання: ultras - ультpac і hooligans хулігани, за якими стоять цілком різні поняття. Ультрас - це футбольний рух; організовані групи підтримки футбольних команд, які привертають до себе увагу на стадіонах — своїм зовнішнім виглядом, розвішуванням прапорів і транспарантів, співом та оплесками, використанням піротехніки. Ультрас це фанати певної футбольної команди, які здійснюють їі мирну підтримку на всіх матчах, включаючи виїзні; вони люблять побешкетувати на стадіоні, проте роблять це відкрито. Рух ультрас ще називають італійським стилем уболівання. Хулігани - це організовані групи радикально налаштованих фанатів, їхній відмінний спосіб вираження своєї відданості улюбленій команді полягає в застосуванні агресії та вчинення насильства стосовно фанатів інших футбольних клубів. Хулігани, на відміну від ультрас, на трибунах намагаються не візуалізуватися, прагнуть не дуже виділятись із натовпу й діють на своєму хуліганському рівні, влаштовуючи бійки 3 фанатами суперників та сутички 3 поліцією. Футбольний хуліганізм притаманний англійському стилю вболівання.

Усі футбольні рухи більшості країн Свропи мають свій домінантний характер уболівання - або ультрас (Італія, Іспанія, Голландія), або хулігани (Великобританія, Греція, Росія, Сербія, Туреччина). Але є країни, в яких ра-

\footnotetext{
${ }^{1}$ A. Markowski, Wykłady z leksykologii, Warszawa 2012, s. 151.

${ }^{2}$ Електронний ресурс: http://www.ultras.com.ua (26.03.2013).
} 
зом співіснують обидва різновиди футбольного фанатизму (Німеччина, Польща, Хорватія), але нерідко ультрас та хулігани одного й того ж клубу майже не контактують. Водночас деякі фахівці говорять про сучасну тенденцію футбольного фанатизму - змішування стилю ультрас і хуліганів, що отримало назву „хультрас "’3. В Україні склалася ще інша ситуація: здебільшого організовані групи підтримки українських футбольних команд декларують італійський стиль уболівання і називають себе ультрас, проте в багатьох українських клубів $\epsilon$ й свої угруповання хуліганів, деякі ж клуби мають серед своїх прихильників або тільки хуліганів, або ж тільки ультрас. Загалом, на українській футбольній фанатській сцені домінує рух ультрас.

Спільноту футбольних уболівальників творять люди, для яких підтримка певної команди $є$ виявом групової ідентичності. У спільноті футбольних фанатів можна помітити певні елементи структури та ієрархії суспільних ролей. Підтримку організовують ультрас (ультрас (ultras (від латинського ultra який знаходиться поза межами; найбільший, крайній або гранично, дуже, надзвичайно 4 ), ультраси (множ.) - футбольні фанати, організовані в групи для активної підтримки улюблених футбольних команд за допомогою візуальних (шалики, прапори, банери), акустичних (спів, оплески, барабанний бій) та піротехнічних (дими, фаєри, стробоскопи) засобів), які займають місця у „своїй” частині стадіону, тобто в секторі. Вони, як правило, одягнуті в барви клубу, часом із розмальованими обличчями. Саме ультраси шиють і розвішують банери (саморобні транспаранти - полотнища величезного розміру з емблемою клубу, фанатського угруповання чи написом, які уболівальники розміщують під час матчу на трибунах чи розвішують на огорожах внизу секторів), провадять словесну сутичку з прихильниками протилежної команди, співають і плескають, скандують заряди, вимахують шаликами і прапорами, запалюють піротехнічні засоби, кидають касові стрічки, серпантин. Ультрас найчастіше відповідають за придбання фаєрів (фаєр (fire) - вогонь, факел, димова граната, піротехнічний заряд), виготовлення найбільших прапорів і банерів та організацію виїздів (поїздок фанатів в інше місто, країну на виїзний матч своєї команди). Фанатські групи ультрас має більшість українських футбольних клубів: Banderstadt Ultras, Ultras 1312, Green Lions, Lviv Ultras - львівські „Карпати”; Metallurg Ultras - донецький „Металург”; Black-White Ultras - луганська „Зоря”; FCDK Ultras, Ultras Dynamo, Support Dynamo Kyiv, Ultras Group FCDK, White-Blue, Kyiv City Supporters - київське „Динамо”; Za Boys Ultras, FCSD Supporters - донецький „Шахтар”; Dnipro Ultras, DSG (Dnepr Support Group) - дніпропетровський „Дніпро”; Ultras Volyn — луцька „Волинь”; Ultras Kharkiv, United Kharkiv, Kharkiv City Patriots - харківський „Металіст”; Ultras Odessa, Ultras Marines - одеського „Чорноморця”; Vorskla Ultras, White-Green Suporters - полтавська „Ворскла”; Ultras Sich - запорізького „Металурга”; Obolon Ultras - київської „Оболоні”; Ultras Arsenal — київського „Арсенала”; FCKK Ultras, Roter Blitz Ultras - криворізького „Кривбаса”; Old Fans Kremin - кременчуцького „Кременя”; TSFC Ultras — сімферопольської „Тавріï”, Leopolitans Ultras - футбольного клубу „Львів”.

Стиль уболівання цих груп відображено в їхніх назвах, де обов'язковим компонентом $є$ слово ультрас, записане латинкою. Проте $є$ групи ультрас, які не

\footnotetext{
${ }^{3}$ Електронний ресурс: http://www.spiegel.de/sport/fussball/0,1518,488211,00.html (12.03.2013).

${ }^{4}$ Великий тлумачний словник сучасної украйнської мови, уклад. і голов. ред. В. Т. Бусел, Київ-Ірпінь 2001, с. 1293.

${ }^{5}$ Електронний ресурс: http://www.ultras.com.ua (17.05.2013).
} 
підтримують цю тенденцію номінування й у своїх назвах використовують кирилицю, напр.: „Завжди вірні”, „Бандерштадm” - ультрас львівських „Карпат”, „Дніпро Великий” - фанати дніпропетровського „Дніпра”, „Харків 1925” фани харківського „Металіста”, „Запорізька Січ”, „Запоріжиі” — ультрас запорізького „Металурга”, „Оболонь 1992” - фанати київської „Оболоні”. Про себе на одній з інтернет-сторінок футбольні фанати пишуть так: „Ультрас — це найбільш фанатичні уболівальники певного клубу, які готові до найбільшої посвяти. Для них має значення практично все, що пов'язане з їхньою улюбленою командою, починаючи від спортивного боку і закінчуючи фанатським"6. Більшість ультрас не беруть участі в бійках. Якщо їм і доводиться битися, то лише тоді, коли на них нападають, чи у виняткових ситуаціях. Вони задіяні насамперед у підтримці власної команди, виїздах, поліпшенні презентації клубу на власному стадіоні тощо. У середовищі ультрас є фанати, які малюють банери й розписують символікою клубу стіни чи паркани в містах, використовуючи для оформлення стиль графіmi; їх називають графітчиками (від італійського graffito - техніка декоративного оздоблення стін будівель ${ }^{7}$ ). Ультрасів, які відповідають за придбання піротехнічних засобів й організацію піротехнічного шоу під час матчу, звуть піротехніками.

Окрему групу становлять хуліганс, хулз (хуліганс (hooligans), хулз (hools) (від англійського hooligan - хуліган $\left.{ }^{8}\right)$ - хулігани, фанати, для яких підтримка футболістів під час матчу є справою другорядною; бачать своє покликання насамперед в бійках із фанатами інших клубів) — люди, які нерідко після футбольного матчу організовують розбірки з уболівальниками команд-суперниць та бійки з міліцією. Пріоритетною справою для них $є$ перемога над іншими уболівальниками в ім'я свого клубу. Менший ентузіазм у них викликає участь в організації підтримки своєї команди. Зазвичай хуліганс на стадіонах не візуалізуються, проте інколи в банерній лінї на огорожах можна побачити i їхні банери-ідентифікатори, напр., банери хуліганських фірм фанатів українських футбольних команд: Darnitsa Hools - київського „Динамо”; Volyn Dogs' Firm - луцької „Волині”; F.C.V.P. hooligans, White-Green Brothersполтавської „Ворскли”; Lviv City Firm — львівських „Карпат”. Для хуліганс матч починається не тоді, коли суддя дасть свисток про початок, а тоді, коли в полі їхнього зору з'являються ворожі фанати. Підтримка футболістів під час матчу є для них справою другорядною. Проте вони не позбавлені честі: б'ються тільки з рівними собі, не зачіпають перехожих, не воюють з підлітками, бо така бійка не приносить їм престижу. Тому шукають достойних суперників, насамперед уболівальників, убраних у барви супротивника, та під час конфронтації 3 ними доводять свою вищість, доказом чого є таке висловлювання футбольного фаната: „Справжні хулігани не нищать потягів, автобусів, тролейбусів, трамваїв, метро чи інших об'єктів тільки задля власної приємності. Вони вміють поводитись гідно стосовно своїх супротивників (наприклад, не чіпати тих, хто вже опинився поза бійкою, не атакувати, коли зустрінуть уболівальника-одинака 3 протилежної групи). Удосконалюють свої вміння постійними тренуваннями, вправляючись у різних бойових мистецтвах. Важливою рисою хуліганів $\epsilon$ також їхня активна участь у проведенні атаки (велика їх кількість показує, що

\footnotetext{
${ }^{6}$ Електронний ресурс: http://www.fanat.ua (19.03.2013).

${ }^{7}$ Словник іншомовних слів, за ред. О. С. Мельничука, Київ 1985, с. 222.

${ }^{8}$ Новий англо-украйнський словник, склав М. І. Балла, Київ 2004, с. 254.

${ }^{9}$ Електронний ресурс: http://www.ultras.com.ua (04.05.2013).
} 
ця група є добре організованою)"”10. Варто звернути увагу, що hooligans, official hooligans - лексема, яка в мовленні українських футбольних фанатів уживається здебільшого в англійському звуковому, а нерідко й графічному, оформленні, має у фанатському соціолекті, на відміну від загальновживаної мови, позитивну конотацію. Таке, цілком протилежне, забарвлення слова хуліган у загальновживаній мові й уболівальницькому соціолекті пов'язане 3 тим, що українські футбольні фанати запозичили цю назву від британських футбольних $\boldsymbol{x y л i - ~}$ $\boldsymbol{t a \boldsymbol { c }}$, які свої радикальні фанатські угруповання називають так на честь першого організатора груп футбольних фанатів — ірландця Едварда Хулігана (Edvard Hooligan), якому належить ідея започаткування фанатського руху у Великобританії ще у $80-\mathrm{x}$ рр. XIX століття ${ }^{11}$.

3'ясування стосунків між хуліганс двох команд називають третім таймом, бо це найчастіше відбувається після матчів. Перечитування інтернет-сторінок та друкованих фанатських газет - фанзинів, які видають уболівальники різних клубів, переконує, що подекуди важливішим від підтримки власної команди під час матчу $є$ боротьба з фанатами супротивника. Нерідко в повідомленнях фанів нема ні слова про гру команди, за яку вболівають, бо найсуттєвішими подіями $є$ сутички й бійки з представниками супротивника. Серед хулз $є$ група гардкорів (гардкори (хардкори) (hardcore - від hard - букв. твердий, міцний, сильний, тяжкий ${ }^{12}$ та соге - серцевина, середина, осердя, ядро $\left.{ }^{13}\right)$ - фанати, які безпосередньо беруть участь у бійках - махачах). Поза футбольним полем боротьба між хуліганс різних команд перероджується в справжню війну. Однак війни ведуть із фанатами далеко не всіх клубів, а тільки з тими, з ким склалися погані стосунки. Так напр., друзями фанатів київського „Динамо” вважаються дніпропетровський „Дніпро” й львівські „Карпати”, а ворогами - одеський „Чорноморець”, донецький „Шахтар”, харківський „Металіст”, запорізький „Металург”. Деякі вболівальницькі війни є такими затятими, що тривають по кілька десятиліть. Для успішного протистояння фанати деяких клубів навіть утворюють „коаліції”, зокрема найвідомішою $є$ „мтріада” (тріада - єдність, утворювана трьома окремими особами, предметами, поняттями або частинами, елементами $\left.{ }^{14}\right)$ - коаліція фанів трьох клубів - „Динамо”, „Дніпра” та „Карпат”, що разом воюють проти спільних давніх супротивників — „Чорноморця” й „Шахтаря”.

Фанатів, які вчащають на виїзні матчі своєї команди, називають виїздюками (від виїзд — дія за значенням виїздити, виїжджати — їхати, відправлятися звідки-небудь, за межі чогось, кудись $\left.{ }^{15}\right)$, а тих, хто не пропустив жодної виїзної гри, - золотими виїздюками (від золотий — дуже цінний, вартий поваги (про людину) ${ }^{16}$ ), адже вважається, що фанат, який побував на всіх матчах улюбленої команди в інших містах чи країнах, зарахував золотий сезон, а тому набуває особливої поваги серед колег. Нерідко футбольні фанати влаштовують „виїзди $y$ стилі 80-x", тобто подорожують на матчі найдешевшим видом громадського транспорту - електричками (собаками). Тому прихильників таких поїздок на футбол називають кінологами (від кінологія — розділ зоології, що вивчає собак, їхні породи, догляд за собаками $\left.{ }^{17}\right)$. Натомість уболівальників, які не $\epsilon$ фанатами,

\footnotetext{
${ }^{10}$ Електронний ресурс: http://www.fanat.ua (10.04.2013).

11 Там само.

${ }^{12}$ Новий англо-украӥнський..., с. 244.

13 Там само, с. 129.

${ }^{14}$ Великий тлумачний словник..., с. 1269.

${ }^{15}$ Там само, с. 95.

${ }^{16}$ Там само, с. 381.

${ }^{17}$ Там само, с. 429.
} 
але часом їдуть 3 ними на виїзні матчі, йменують муристами (турист - той, хто займається туризмом $\left.{ }^{18}\right)$; від туризм - подорожі, які здійснюються за певними маршрутами по своїй країні або за кордоном ${ }^{19}$ ). Дуже юних фанатів називають „карлюками” (від карлик - неприродно мала на зріст людина; ліліпут, коротун, куцак, куцан ${ }^{20}$ ), недофанатами (від недорослі (недорослий - який ще не виріс, перебуває в дитячому віці; малолітній ${ }^{21}$ ) фанати) або школотою (контамінація слів школа і голота).

Члени фанатської спільноти виокремлюють на стадіоні ще групу звичайних уболівальників, яких називають кузьмичами, кузьмою, кузьмотою, кузею та $\boldsymbol{K u Z}$ (від патроніма Кузьмич, Кузьмович, утвореного від антропоніма Кузьма $\left.{ }^{22}\right)$. Кузьма — це футбольні уболівальники, які, прийшовши на футбол, як правило, не беруть участі в активній підтримці своєї команди, зазвичай увесь час сидять під час матчу, приносять із собою на стадіон пиво, харчі, лузають смажене насіння, нерідко влаштовуючи на трибуні пікнік (для порівняння у польській мові таких уболівальників називають пікніковцями (piknikowcy)); вони ніколи не їздять на виїзні матчі. Таких уболівальників ще називають простими вболівальниками 3 кульками, пересічними вболівальниками чи сємкопожирачами, сємкоӥдами, сємками ${ }^{23}$ (від російського сємєчкі, сємки насіння (найчастіше соняшника або гарбуза)). „Становлять вони щоправда найбільшу частину українських стадіонів. Це уболівальники, які цікавляться тільки виключно спортивним аспектом матчу. Уболівальницькі справи не цікавлять їх цілком або цікавлять від випадку до випадку, напр., в аспекті одягання на себе барв клубу. Підтримують команду, коли виграє, а коли їй не щастить довший час здолати суперників, часто від неї відвертаються. Не готові до посвяти своїй команді" 24 . Саме зі секторів кузьмичів можуть лунати образливі вигуки, адресовані футболістам власної команди, наприклад львівські вболівальники, незадоволені діями своїх гравців на полі, можуть вигукувати: „Вівці!’. „Коли на власному полі „Карпати” грають невдало, без самовіддачі і вболівальників не влаштовує результат або гра команди, з трибун на адресу футболістів інколи лунають вигуки „Вівці! Вівці!”. Таке унікальне прізвисько не вживають більше ніде в Україні. Воно відоме у Львові ще з кінця 1960-х років"25. Таких вигукувань ніколи не дозволяють собі натомість фанатські сектори. Найбільшим виявом зневаги футбольних фанатів до своїх футболістів чи клубних функціонерів, $\epsilon$ мовчазне спостерігання за матчем, коли фани сидять і не підтримують команду оплесками, співом тощо, або коли фанати обертаються спинами до футбольного поля. Проте до такого демонстрування свого незадоволення фанати вдаються вкрай рідко й, здебільшого, упродовж лише одного з таймів матчу. Про кузьмичів на львівському стадіоні прихильно відгукуються фанати з інших українських міст, кажучи, що „львівська кузьма — дресирована — підтримує переклички та заряди"26.

\footnotetext{
${ }^{18}$ Там само, с. 1277.

19 Там само, с. 1276.

${ }^{20}$ Там само, с. 418.

${ }^{21}$ Там само, с. 600. ред. В. М. Русанівського, Київ 1996, с. 231.

${ }^{23}$ Електронний ресурс: http://www.ultras.com.ua (16.01.2013).

${ }^{24}$ Електронний ресурc: http://www.fanat.ua (21.02.2013).

${ }^{25}$ Електронний pecypc: http://fckarpaty.com.ua (13.04.2013).

${ }^{26}$ Електронний ресурс: http://www.ultras.com.ua (21.03.2013).
}

${ }^{22}$ Власні імена людей: словник-довідник, уклад. Л. Г. Скрипник, Н. П. Дзятківська, за 
Серед кузьми є чимало таких, які приходять на футбол у клубних шаликах. Таких уболівальників футбольні фанати називають скарферами (ска(p)фер (scarfer) від scarf - шарф $\phi^{27}$ - звичайний уболівальник, який носить шарф зі символікою улюбленої команди й приходить на матч іiі підтримувати). Окрему групу в середовищі кузьмичів становлять уболівальники 3 дудками - дyдарики (дударик — зменшено-пестливе до дудар; дудар — той, хто грає на дудці, сопілці $\left.{ }^{28}\right)$ — ті, які підтримують свою команду за допомогою дудок; до них футбольні фанати ставляться зневажливо, нерідко вигукуючи: „Дудки геть зі стадіону!". Проте футбольні фанати цілком толерують мовчунів (мовчун той, хто звичайно мовчить, не любить багато говорити; той, хто не висловлює своїх думок ${ }^{29}$ ) чи muxapis (від тихий — який звичайно не проявляє різко чи бурхливо своїх почуттів; спокійний ${ }^{30}$ ) — уболівальників, які мовчки дивляться футбол. Раніше серед таких були насамперед солдати строкової служби, яких примусово приводили на стадіон і розсаджували внизу по периметру секторів.

Стрижневою для мовної картини світу футбольних уболівальників є опозиція „свій — чужий”, яка є суттєвою категорією вираження інтелектуального й емоційного ставлення до оточуючого світу, адже часто лише присутність чужого дозволяє їм окреслити себе. „Чужий” — це той, хто мислить по-іншому ніж „ми”, живе по-іншому, виглядає по-іншому, визнає інші цінності. Немає стереотипу „чужого” без стереотипу „свого”. Простіше кажучи: „чужі”, тобто „вони”, є потрібні, щоб „ми”, тобто „свої”, були сильними, міцними, ліпшими. Таке переконання щодо власної спільноти стає підставою для формулювання неписаного кодексу поведінки. „Ми” - це вболівальники власної команди. „Чужі” - це вболівальники команди-суперниці, з „чужими” треба воювати. Як уважає польська дослідниця Ева Колодзєєк, „Характерною рисою субкультури стадіонів, яка відрізняє їх від інших сучасних групових культур, $є$ імператив боротьби. Можна припустити, що ... найістотнішим, найсильнішим суспільним зв’язком, який єднає членів цієї групи є не стільки вболівання за власну команду, скільки війна з уболівальниками команд-супротивників. Так, ніби жагу боротьби, яка панує на футбольному полі між двома футбольними командами, перенесено на їхніх уболівальників"з1.

„Чужими”, тобто ворогами, для фанатів є насамперед команди-суперниці та їхні вболівальники. Саме вони є адресатами вигуків і скандувань, які лунають 3 трибун i, як правило, мають провокативний характер. На стадіоні триває гостра словесна боротьба, напр.: „Хохол народився - жнид заплакав!” (висловлювання фанатів київського „Динамо”, які мають прізвисько хохли (хохол зневажлива назва українця ${ }^{32}$ ), спрямоване до фанів одеського „Чорноморця”, яких прозивають жнидами (жиди - 1) те саме, що євреї; 2) образлива назва євреїв $\left.{ }^{33}\right)$ ) або: „Зелено-білі барви — колгоспник їх не достойний!” (текстовик фанів львівських „Карпат”, для яких зелено-білі барви є клубними, звернений до фанатів полтавської „Ворскли”, що теж виступає в біло-зелених кольоpax; фанати інших українських клубів зневажливо називають „Ворсклу” та іiі

\footnotetext{
${ }^{27}$ Новий англо-украӥнський..., с. 468.

${ }^{28}$ Великий тлуммачний словник..., с. 251.

${ }^{29}$ Там само, с. 535.

${ }^{30}$ Там само, с. 1248.

${ }^{31}$ E. Kołodziejek, Człowiek i świat w języku subkultur, Szczecin 2005, s. 110.

${ }^{32}$ Великий тлумачний словник ..., с. 1351.

${ }^{33}$ Там само, с. 275.
} 
фанів колгоспниками (колгоспник - член колгоспу ${ }^{34}$ ) - за першою назвою полтавської футбольної команди — „Колгоспник”, яку вона мала з 1955 до 1984 рр.)).

Ще однією групою „чужих”, тобто ворогів для фанатів, проти яких можуть об'єднатися навіть непримиренні фанатські угруповання, що здавна ворогують між собою, є міліціонери. Найчастіше в середовищі фанатів використовують такі зневажливі й образливі назви співробітників міліції - вовкулаки, кашкети, мснти, мусори, А.С.А.В., акаби, акабери, асав, копи, лягаві, недолюди, погони, самбісти, регбісти, слони (від російської абревіатури С.Л.О.Н. - смерть лягавим од (від) ножа). Більшість наведених вище найменувань міліції вживають у сучасному жаргонному мовленні, за винятком лексеми A.C.A.B., що функціонує тільки серед футбольних фанатів. Ця англійська абревіатура виражає ненависть до правоохоронців (A.C.A.B. - 3 англ. all coppers are bastards - усі поліціянти покидьки), нею повсюдно рясніють паркани й стіни будинків у містах. Бійців ОМОНу, яких нерідко залучають до охорони матчів, називають космонавтами (космонавт - той, хто здійснює польоти в космічному просторі ${ }^{35}$ ) через зовнішню подібність їхнього повного бойового обмундирування до скафандрів космонавтів. Беркутами чи беркутяmaмu (від беркуm - великий хижий птах із породи орлів ${ }^{36}$ ) називають міліціонерів зі спецпідрозділу „Беркут”, а грифонами (грифон - те саме, що гриф; гриф - великий хижий птах ряду соколоподібних, який живе в деяких горах i живиться падаллю ${ }^{37}$ ) - бійців із підрозділу „Грифон”, які допомагають у забезпеченні порядку до, під час та після футбольних матчів. Узагальнити ставлення фанатів до міліції можна цитатою з банера ультрас ужгородського „Закарпаття”: „Футбол для фанів, а не для мусорів”з8.

Ворогом фанатів $\epsilon$ також охорона стадіону, яка повинна пильнувати за порядком під час матчу і яка знає, як протистояти заворушенням, але часто вона виводить із сектора надміру активних фанатів. Тому охоронців-стюардів нерідко звуть церберами (цербер - лютий і пильний охоронець ${ }^{39}$ ). Негативне ставлення до охорони стадіону пов'язане й із тим, що вона разом із міліцією влаштовує фанатам перед тим, як пропустити на стадіон, имон - обшук уболівальників, відбираючи при цьому піротехніку тощо.

Брутальними й вульгарними є вигуки до суддів, які, на думку вболівальників, припускаються помилок на користь команди-суперниці, підсуджують їй. Найобразливішими вигуками в бік рефері $є$ називання його всіма можливими синонімами до слова гомосексуаліст: „Суддя- гей!”, „Суддя - niдерас!”, „Суддя - тридвараз!” (останній приклад є заміною ненормативного слова п...c близьким до нього за звучанням висловлюванням (від три - два — раз)). Арбітрів нерідко називають антропонімами Валера, Валєра (від Валера зменшено-пестливий варіант імені Валерій ${ }^{40}$ ), які у фанатському соціолекті $\epsilon$ синонімами до перелічених вище найменувань. У свідомості фанатів судді це люди, які зазвичай бувають необ'єктивними й за певну фінансову винагороду діють на користь однієї з команд. Варто звернути увагу, що в сучасних стадіонних скандуваннях, спрямованих до судді рідко використовують та-

\footnotetext{
${ }^{34}$ Там само, с. 439.

${ }^{35}$ Там само, с. 458.

36 Там само, с. 48.

37 Там само, с. 198.

${ }^{38}$ Електронний ресурс: http://www.ultras.org.ua (06.06.2013).

${ }^{39}$ Великий тлумачний словник..., с. 1361.

${ }^{40}$ Власні імена людей..., с. 44.
} 
кий популярний колись вигук, яким виражали незадоволення діями арбітра: „Суддю на мило!”.

До ворогів уболівальники зараховують також футбольних функціонерів, яких вони звинувачують у корисливості, нечесності, продаванні (зливі) матчів, здійсненні фінансових махінацій із метою отримання зиску або ж накладанні штрафних санкцій на футбольні клуби. На українських стадіонах часто можна було почути вигуки про колишнього голову Федерації футболу України Григорія Суркіса, якого фанати звуть Шубкісом (після відомої афери з підкупом іноземних суддів подарунками-шубами): „Суркіс — жид!”, „Бай, бай, Гриша!”. На львівській арені фанати неодноразово апелювали до почесного президента „Карпат” Петра Димінського, якого називають Димом чи Демоном, напр.: „Дим, досить продавати матчі! Кращзе продай клуб!”. Федерацію футболу України, Контрольно-дисциплінарний комітет якої нерідко штрафує футбольні клуби чи знімає очки за недостойну, на думку чиновників, поведінку фанатів, уболівальники називають Педерацією. Ось приклад одного із текстовиків, зверненого до функціонерів футбольної федерації: „Геть брудні масонські лапи від „, Металіста” $i$,, Kapnam”!"41 (натяк на приналежність очільника Федерації Григорія Суркіса до масонів).

Підсумовуючи, зазначимо, що в мовній картині світу футбольних фанатів вербалізовано лише невеликий фрагмент навколишньої дійсності, пов'язаний зі сферою, що формує суспільні зв' язки цієї групи - спільне вболівання за певну команду.

Стрижневу для соціолекту опозицію „свій — чужий” репрезентують дві групи номінацій: 1) назви фанатських угруповань та команд, за які вони вболівають та 2) назви, які використовуються для номінування „ворогів” фанатів — міліції, охорони стадіонів, суддів, футбольних функціонерів тощо. Як показав аналіз, більшість лексем цих тематичних груп є назвами, утвореними семантичним способом унаслідок переосмислення значень загальновживаних слів мови, рідше шляхом деривації; є також і чимала частка запозичень, насамперед із молодіжного жаргону, а також із різних чужих мов.

${ }^{41}$ Електронний ресурc: http://www.ultras.com.ua (10.12.2012). 